\title{
Low Serologic Prevalences Suggest Sporadic Infections of Hepatitis E Virus in Chamois (Rupicapra rupicapra) and Red Deer (Cervus elaphus) in the Italian Alps
}

\begin{abstract}
Tiziana Trogu, ${ }^{1,6}$ Nicola Ferrari, ${ }^{1,5}$ Nicoletta Formenti, ${ }^{2}$ Filipello Virginia, ${ }^{2}$ Luca Pedrotti, ${ }^{3}$ Roberto Viganò, ${ }^{4}$ Paolo Lanfranchi, ${ }^{1}$ and Camilla Luzzago ${ }^{1,5}{ }^{1}$ Department of Veterinary Medicine, University of Milan, via Celoria 10, 20133 Milan, Italy; 'Experimental Zooprophylactic Institute of Lombardy and Emilia-Romagna "Bruno Ubertini", via Bianchi 7/9, 25124 Brescia, Italy; ${ }^{3}$ Stelvio National Park, via De Simoni 42, 23032 Bormio (SO), Italy; ${ }^{4}$ AlpVet Associates, piazza Venzaghi 2, 21052 Busto Arsizio (VA), Italy; ${ }^{5}$ Coordinated Research Center “EpiSoMl”, University of Milan, 20133 Milan, Italy; ${ }^{6}$ Corresponding author (email: tiziana.trogu @ gmail.com)
\end{abstract}

ABSTRACT: Hepatitis E virus (HEV) is a worldwide public health concern, with an increase in human autochthonous cases in Europe. Although domestic pigs and wild boar (Sus scrofa) are the main reservoirs of $\mathrm{HEV}$, the constant expansion of wild ruminants increases the potential for $\mathrm{HEV}$ transmission. We investigated HEV infection in chamois (Rupicapra rupicapra) and red deer (Cervus elaphus) in the Italian Alps using an enzyme-linked immunosorbent assay (ELISA). We detected HEV antibodies from 2013 to 2015 in both host species, with seroprevalences of $1.2 \%$ and $0.8 \%$ in chamois and red deer, respectively. All serum samples that were positive to $\mathrm{HEV}$ antibodies by ELISA were negative when tested by real-time reverse-transcriptase PCR to detect HEV RNA. The observed low seroprevalence of HEV suggested a sporadic circulation of HEV in the alpine environment, and it was consistent with the low seroprevalence observed in wild boar in the Alps. Our observations supported the role of chamois and red deer as spill-over hosts of HEV infections in the Italian Alps.

Key words: Chamois, hepatitis E virus, Italy, red deer, seroprevalence.

Hepatitis E virus (HEV) of the Hepeviridae family represents a worldwide public health issue, with an increase of human cases acquired in Europe (Aspinall et al. 2017). Fecal-oral transmission is the most common route of $\mathrm{HEV}$ transmission and infections in humans may occur by means of virus-contaminated water, consumption of raw or undercooked meat, and by direct contact with infected animals (Rutjes et al. 2010; Van der Poel, 2014). Moreover, HEV is very resistant under environmental conditions, providing high persistence (Parashar et al. 2011).

Currently, eight genotypes (1-8) of $\mathrm{HEV}$ are recognized (Al-Sadeq et al. 2018) and characterized by different geographic distribution (Zehender et al. 2014; Hakim et al. 2017). The spectrum of receptive hosts is unknown and the ever-expanding host range poses a significant concern for understanding the source of zoonotic HEV infections (Meng 2016). The different ecologic interactions among its numerous host species make HEV epidemiology difficult to understand, and the reservoirs and spill-over hosts are yet to be defined (Pavio et al. 2017; King et al. 2018). Domestic pig and wild boar (Sus scrofa) are considered to be the main reservoirs of $\mathrm{HEV}$ while deer have been reported as spill-over hosts in European countries (Boadella 2015; Anheyer-Behmenburg et al. 2017; Spancerniene et al. 2018).

The seroprevalence of $\mathrm{HEV}$ in wild boar in the Alps and in prealpine areas ranges from $4.9 \%$ to $10.2 \%$ (Caruso et al. 2015; Martinelli et al. 2015), likely related to scattered and irregular presence of this host. In the central Italian Apennine mountain range, where wild boars are abundant, high HEV seroprevalences were detected reaching 48.7\% (Martinelli et al., 2015). No information is available for $\mathrm{HEV}$ infection in alpine wild ruminants, and the relationship between $\mathrm{HEV}$ infection in wild ruminants and wild boars needs investigation. In particular, red deer (Cervus elaphus) are expanding their distribution and have a spatial overlap with wild boar. Alpine chamois (Rupicapra rupicapra) are the most abundant wild ungulate in the Alps (Carnevali et al. 2009), but their high mountain habitat limits interactions with wild boar and a lower exposure to $\mathrm{HEV}$ is expected. We aimed to serologically investigate $\mathrm{HEV}$ in chamois and 
red deer in order to provide basic epidemiologic patterns of this infection in alpine wild ruminants.

Sampling was carried out from 2013 to 2015 during autumnal hunting seasons and depopulation plans in three study areas. Area 1 was in the Lepontine Alps (northwestern Italian Alps), where populations of investigated species have an estimated density of 6.7 chamois $/ \mathrm{km}^{2}$ and 2 red deer $/ \mathrm{km}^{2}$ (VCO2 2014). Area 2 was the Orobic Alps (southeastern Italian Alps), with a density of 8.2 chamois $/ \mathrm{km}^{2}$ (De Liberato et al. 2015). Area 3 was in the Stelvio National Park (central eastern Italian Alps) with a mean density of $9.5 \mathrm{red}$ deer $/ \mathrm{km}^{2}$ (Raganella Pelliccioni et al. 2013). In Areas 1 and 2, there was a low, but strongly increasing, density of wild boar $(0.1-$ 0.5 animals $/ \mathrm{km}^{2}$; Carnevali et al. 2009). No wild boars were present in Area 3 (Stelvio National Park 2019). Chamois were sampled in Areas 1 and 2 while red deer were sampled in Areas 1 and 3. The age for each animal was estimated by tooth eruption patterns, identifying three age classes: kid $(<1 \mathrm{yr})$, yearling $(1$ $\mathrm{yr}$ ), and adult ( $>2 \mathrm{yr}$ ).

Blood samples were collected in the field from major blood vessels during animal bleeding or from the cardiac clot at the hunting control centers. After centrifugation at $242 \times \mathrm{G}$ for $15 \mathrm{~min}$, highly hemolyzed sera were excluded and the remaining samples were stored at $-20 \mathrm{C}$.

A total of 172 chamois and 254 red deer sera were collected. Samples were collected from 128 chamois from Area 1, 44 chamois from Area 2, and 81 and 173 red deer from Areas 1 and 3, respectively. Sera were tested by a species-independent enzyme-linked immunosorbent assay (HEV ELISA 4.0v, MP Diagnostics-Biomedicals, Singapore), previously used in wild boar and cervids (Rutjes et al. 2010; Thiry et al. 2017), which simultaneously detects immunoglobulins $\mathrm{M}$, $\mathrm{G}$, and A formed against HEV recombinant protein ET2.1 (Hu et al. 2008). The ELISA was performed according to manufacturer recommendations using the cut-off values they recommended. We calculated seroprevalence and confidence limits using the Wilson method (Brown et al. 2001). Positive sera for $\mathrm{HEV}$ antibodies were individually tested for the presence of HEV RNA using a one-step real-time reverse-transcription PCR (qRTPCR (Jothikumar et al. 2006).

Chamois and red deer showed a HEV seroprevalence of $1.2 \%(2 / 172 ; 95 \%$ confidence interval [CI]: 0.3-4.1 exact Wilson) and 0.8\% (2/254; 95\% CI: 0.2-2.8), respectively. Seropositive chamois were two females, 2 and 7 yr old from area 1, while seropositive red deer were from area 1 (one female 7-9 yr old) and area 3 (one female over 15 yr old). The mean optical density and standard deviation $(\mathrm{OD} \pm \mathrm{SD})$ values for negative and positive samples were $0.02( \pm 0.03)$ and $0.52( \pm 0.17)$, respectively, for chamois; $0.01( \pm 0.03)$ and $0.25( \pm 0.02)$ for red deer. All samples tested negatively for HEV RNA.

We report HEV circulation in chamois and red deer in alpine environments, showing a low prevalence of HEV antibody. The low prevalences were observed during a 3-yr monitoring plan, suggesting that $\mathrm{HEV}$ has a sporadic presence in both hosts in the Alps. Although wild boar are known to be a reservoir of $\mathrm{HEV}$, this species shows a wide range of seroprevalences in Italy, ranging from $4.9 \%$ to $48.7 \%$, with the highest values in central Apennines (Martinelli et al. 2015) where this host is abundant. Red deer share habitat in this area with an increasing number of wild boar and had the highest HEV seroprevalence (13.9\%; Di Bartolo et al. 2015). On the other hand, our finding of a sporadic presence of $\mathrm{HEV}$ in red deer is consistent with the low prevalence observed in wild boar in alpine and prealpine environments (Caruso et al. 2015; Martinelli et al. 2015). These observations support the role of red deer as a spillover host from wild boar population in the Alps.

However, we detected HEV-positive sera in a red deer in Stelvio National Park, where wild boar are not present, and in a chamois, a host species that usually lives in remote, highaltitude habitats where interactions with wild boars and humans are limited. Therefore, we cannot rule out other, unknown sources of infection for alpine wild ungulates besides 
wild boar. Currently, data about seroprevalence in livestock within the study area are not available.

The ongoing expansion of wild boar populations throughout a wide spectrum of habitat types, including alpine grasslands over 2,000 $\mathrm{m}$ in elevation (Massei et al. 2015), could lead to more interspecific interactions and thus to the increase of $\mathrm{HEV}$ spread. The HEV detection in alpine ruminants should be further considered in relation to the public health implications linked to the hunting activity and game meat consumption, considering the high number of chamois and red deer (about 13,000 and 10,000 respectively) culled in Italy every year (Raganella Pelliccioni et al. 2013).

The study was funded by the Italian Ministry of Education, Scientific Research PRIN Grant number: 2010P7LFW4 (201011) "Genomics and host-pathogen interactions: A model study in the One-Health perspective" and by project "Filiera EcoAlimentare" supported by Fondazione Cariplo. All applicable international, national, and/or institutional guidelines for the care and use of animals were followed. Samples were gathered from free-ranging ungulates legally shot by hunters. We thank the hunters and management committee of the hunting districts Alpi Lecchesi, Prealpi Lecchesi (LC), Verbano-Cusio-Ossola 2 (VB), and the staff of the Stelvio National Park for logistic and technical support. A particular acknowledgement is to Andrea Zanoli for field activity and Walter Martelli for laboratory analyses.

\section{LITERATURE CITED}

-Al-Sadeq DW, Majdalawieh AF, Mesleh AG, Abdalla OM, Nasrallah GK. 2018. Laboratory challenges in the diagnosis of hepatitis E virus. J Med Microbiol 67: 466-480.

Anheyer-Behmenburg HE, Szabo K, Schotte U, Binder A, Klein G, Johne R. 2017. Hepatitis E virus in wild boars and spillover infection in red and roe deer, Germany, 2013-2015. Emerg Infect Dis 23:130-133.

-Aspinall EJ, Couturier E, Faber M, Said B, Ijaz S, Tavoschi L, Takkinen J, Adlhoch C. 2017. Hepatitis E virus infection in Europe: Surveillance and descriptive epidemiology of confirmed cases, 2005 to 2015. Eurosurveillance 22:30561.
Boadella M. 2015. Hepatitis E in wild ungulates: A review. Small Rumin Res 128:64-71.

Brown LD, Cai TT, DasGupta A. 2001. Interval estimation for a binomial proportion. Stat Sci 16: 101-117.

Carnevali L, Pedrotti L, Riga F, Toso S. 2009. Ungulates in Italy: Status, distribution, abundance, management and hunting of ungulate populations in Italy-Report 2001-2005. Biol Cons Fauna 117:1-168.

Caruso C, Modesto P, Bertolini S, Peletto S, Acutis PL, Dondo A, Robetto S, Mignone W, Orusa R, Ru RG, et al. 2015. Serological and virological survey of hepatitis $\mathrm{E}$ virus in wild boar populations in northwestern Italy: detection of HEV subtypes 3e and 3f. Arch Virol 160:153-160.

De Liberato C, Berrilli F, Marangi M, Santoro M, Trogu T, Putignani L, Lanfranchi P, Ferretti F, D'Amelio S, Giangaspero A. 2015. Giardia duodenalis in Alpine (Rupicapra rupicapra rupicapra) and Apennine (Rupicapra pyrenaica ornata) chamois. Parasite Vector 8:650

Di Bartolo I, Ponterio E, Angeloni G, Morandi F, Ostanello F, Nicoloso S, Ruggeri FM. 2015. Presence of hepatitis E virus in a red deer (Cervus elaphus) population in central Italy. Transbound Emerg Dis 64:137-143.

Hakim MS, Wang W, Bramer WM, Geng J, Huang F, De Man RA, Peppelenbosch MP, Pan Q. 2017. The global burden of hepatitis E outbreaks: A systematic review. Liver Int 37:19-31.

Hu WP, Lu Y, Precioso NA, Chen HY, Howard T, Anderson D, Guan M. 2008. Double-antigen enzyme-linked immunosorbent assay for detection of hepatitis $\mathrm{E}$ virus-specific antibodies in human or swine sera. Clin Vaccin Immun 15:1151-1157.

Jothikumar N, Cromeans TL, Robertson BH, Meng XJ, Hill VR. 2006. A broadly reactive one-step real-time RT-PCR assay for rapid and sensitive detection of hepatitis E virus. J Virol Methods 131:65-71.

King NJ, Hewitt J, Perchec-Merien AM. 2018. Hiding in plain sight? It's time to investigate other possible transmission routes for hepatitis E virus (HEV) in developed countries. Food Environ Virol 10:225-252.

-Massei G, Kindberg J, Licoppe A, Gačić D, Šprem N, Kamler J, Baubet E, Hohmann U, Monaco A, Ozoliņš J, et al. 2015. Wild boar populations up, numbers of hunters down? A review of trends and implications for Europe. Pest Manag Sci 71:492-500.

Martinelli N, Pavoni E, Filogari D, Ferrari N, Chiari M, Canelli E, Lombardi G. 2015. Hepatitis E virus in wild boar in the central northern part of Italy. Transbound Emerg Dis 62:217-222.

Meng XJ. 2016. Expanding host range and cross-species infection of hepatitis E virus. PLoS Pathog 12: e1005695.

Parashar D, Khalkar P, Arankalle VA. 2011. Survival of hepatitis $\mathrm{A}$ and $\mathrm{E}$ viruses in soil samples. Clin Microbiol Infect 17:E1-E4.

Pavio N, Doceul V, Bagdassarian E, Johne R. 2017. Recent knowledge on hepatitis $\mathrm{E}$ virus in Suidae 
reservoirs and transmission routes to human. Vet Res 48:78.

Raganella Pelliccioni E, Riga F, Toso S. 2013. Linee guida per la gestione degli ungulati. Cervidi e Bovidi. ISPRA, Manuali e Linee Guida 91/2013, Istituto Superiore per la Protezione e la Ricerca Ambientale, Roma, Italia, 225 pp.

Rutjes SA, Lodder-Verschoor F, Lodder WJ, Van der Giessen J, Reesink H, Bouwknegt M, de Roda Husman AM. 2010. Seroprevalence and molecular detection of hepatitis $\mathrm{E}$ virus in wild boar and red deer in The Netherlands. J Virol Methods 168:197206.

- Spancerniene U, Grigas J, Buitkuviene J, Zymantiene J, Juozaitiene V, Stankeviciute M, Razukevicius D, Zienius D, Stankevicius A. 2018. Prevalence and phylogenetic analysis of hepatitis $\mathrm{E}$ virus in pigs, wild boars, roe deer, red deer and moose in Lithuania. Acta Vet Scand 60:13.

Stelvio National Park. 2019. Piano del Parco Nazionale dello Stelvio, 2019. http://lombardia.stelviopark.it/
wp-content/uploads/2019/05/PP_VAS_All.E_ Check-List-Flora-e-Fauna.pdf. Accessed July 2019.

Thiry D, Mauroy A, Saegerman C, Licoppe A, Fett T, Thomas I, Brochier B, Thiry E, Linden A. 2017. Belgian wildlife as potential zoonotic reservoir of hepatitis E virus. Transbound Emerg Dis 64:764-773.

Van der Poel WH. 2014. Food and environmental routes of hepatitis E virus transmission. Curr Opin Virol 4: 91-96.

VCO2 (Ossola Nord Hunting District). 2014. Results of the ungulate census in the VCO2 Ossola Nord. http:// www.vco2.it/risultati-censimenti-ungulati-nel-vco2-ossola-nord/ Accessed July 2019.

Zehender G, Ebranati E, Lai A, Luzzago C, Paladini S, Tagliacarne C, Galli C, Galli M, Ciccozzi M, Zanetti AR, et al. 2014. Phylogeography and phylodynamics of European Genotype 3 hepatitis $\mathrm{E}$ virus. Infect Genet Evol 25:138-143.

Submitted for publication 9 February 2019.

Accepted 1 August 2019. 